\title{
CONTENT OF WOMEN HISTORY IN THE CURRICULUMOF HISTORY FOR SENIOR HIGH SCHOOL COMPARISON STUDY OF 1994, 2004, AND 2006
}

\author{
Budiarti $^{1}$ and Giri Rachmawati Fahmi ${ }^{2}$
}

\begin{abstract}
This paper reviewed the content of women in history in the 1994, 2004 (KBK), and 2006 curriculums. It uses content analysis method. The result of this research shows that the content of women history was not increased and in different in from curriculum to the others. In 1994 Curriculum, women history only focused on the woman organizations in national movement period. In KBK and KTSP, there was women history in Hinduism-Buddhism era, and in the colonial era. In KBK and 2006 curriculums, students could learn more although the material was not as complete as in 1994, but they can learn it from the internet. From the analysis result of the women history narration in history textbook in 1994 Curriculum, KBK, and 2006 curriculums, because of the patriarchy culture and political factor, the writing of women history was androcentric.
\end{abstract}

Keywords: 1994 Curriculum, KBK, KTSP, women history, historiography, history text book, senior high school.

1 Budiarti ia a lecturer at Department of History, Faculty of Social Science, Jakarta State University. For academic interest, the author can be contacted at office address: Komplek UNJ, Jl. Rawamangun Muka, Jakarta Timur 13220.

2 Giri Rachmawati Fahmi was graduated from Department of History, Faculty of Social Science, Jakarta State University. She has been a teacher in Depok. 
BUDIARTI \& RACHMAWATI FAHMI,

Content of Women History in the Curriculum of History for Senior High School Comparison Study of 1994, 2004, and 2006

\section{Introduction}

After Indonesia independence, curriculum started to develop in stages, appropriate with the era. Those started from 1947, 1952, 1964, 1968, 1975, 1984, 1994, 2004, and 2006. In 1994 Curriculum, the completing of 1984 Curriculum, there was a changing in learning time from quarter to semester, it made the materials became more comprehensive than the pervious. Ones in the 2004 Curriculum (KBK), there was a changing again. The curriculum goal was made individual have certain competences. The 2006 Curriculum (KTSP), completies the 2004 Curriculum, there was more changing in the authority so that school could create their own education plan based on the standardization that had been stated: objectives, vision-mission and its curriculum content, structure, education calendar, until the syllabus development.

Curriculum plans every single activity of knowledge in education process; one of the knowledge is history. Since the colonial era, history education had taken an important role in Indonesia curriculum. There is a fact that however changing the curriculum, history subject is always listed as compulsory subject that should belearned by the students (Hasan, 1997: 135). Traditionally, the goals of national curriculum in history subject is for developing students competence to appreciate our past nation, having pride of the nation, loving their motherland, having nation unity and integrity, and making the past as a lesson for present life (Puskur, 2003). The history aspects could be various lessons. Those lesson are set in the history curriculum then detailed by the teachers for their students; one of the resson materials is about women role in history.

In Indonesian history, there are so many roles, acted by both men and women. Women history is a history which contains so many women roles and contributions in the making of a nation. According to Kuntowijoyo, "In Indonesia, women movement has a long history. Since before the independence in 1945, Indonesian women had been active in the independence struggle, like Cut Nyak Dien, Dewi Sartika, R.A. Kartini, and many more (Kuntowijoyo, 2010: 34). In 1928, Indonesian women strengthen their movement with making the first Indonesian Women Congress (Sadli, 2010: 34). It is proved that the political vision and the women independent in Indonesia on social and political aspect are not something new.

This research focused on how the content of women history in national history curriculum. This research tried to describe and analize about women history in Senior High School based on 1994 Curriculum, KBK, and KTSP.

One of research that author had found and relevant with this paper was from Budiarti, entitled 'The Undergraduate Students' History Awareness on Women Role in History' (Postgraduate Program, Jakarta State University, 1994). It describes the fact that only the minimum of undergraduate students' awareness about women role in history. The result of it has motivated author to create the same theme research in senior high school history curriculum. This paper will explain about: (1) patriarchy culture effect in the formulation of national history curriculum in the senior high school, (2) political effect in the writing of Indonesia history, and (3) content of women history in history subject in senior high school based on 1994 Curriculum, KBK, and KTSP.

\section{Method}

There are factors that affect the content of women history: cultural factor 
and political factor. Both of them will be implicated in history text book narration in history curriculum, such as in 1994 Curriculum, KBK, and KTSP. To know how big the content of women history in national history curriculum (1994, KBK, and KTSP), it is needed to look from the syllabus and the learning plan required by each curriculums. This research used text analysis method.

\section{Patriarchy Culture Affects the Historiography}

In the general culture, women are assumed as 'the second sex'. Women role is in domestic sphere. Meanwhile men role is only in public sphere as the breadwinner. Those are the form of patriarchy culture Sadli, 2010: 72). Patriarch itself means father authority. Started as the vocabulary about the family that being dominated by men rule, every young men, boys, slaves, servants, etc., is under the men rule. In a long term, men are looked as a subject that could control and have rights in public area. Men always have power in so many aspects, meanwhile women only positioned as the servant who help men. In society, women's domestic role only connects to bed, kitchen, and well (kasur, dapur, dan sumur).

Patriarchy conception generally used to call a system that located women as the dominated and subordinated by men. Relation between women and men in this concept is a hieratic, men are ruler and women are ruled (Bhasin, 1996:1). Patriarchy conception is constructed, organized, and socialized by the daily institutions, such as family, school, society, religion, working place, until the country regulation.

According to Walby, patriarchyis a system of social structure, a practical condition that positioned men in a dominant position; they can suppress and exploit women. Walby divided patriarchy into two kinds: private patriarchy and public patriarchy. As Walby thought, there is an expansion form from the private area like family and religion, to the public area such as country. This expansion makes patriarchy widen and it is succesded to dominate (Walby: 1989: 213-231).

Patriarchy culture affects also in education aspect. In school, directly and indirectly, there's socialization about patriarchy, such as in its organization until the text book used in school. For example, in a simple sentence, 'Father drinks coffee, and mother cooks in the kitchen.' It shows that there is inculcation about gender bias to the students.

In history, women position as the second sex becomes an uninteresting topic to be taught. Women history is not as heroic as men's. Indonesia history itself is full of the story of men and their weapon. History is more looked like a stage for the greatness of men, meanwhile women role is just as a compliment. For example, in Maluku War 1817, it's always about Pattimura, whereas there's a woman also named Christina Martha Tiahahu who got her own battle to fight the Netherlands. But, her brave and contribution in nation struggle is not known as well as Pattimura by the society, especially by the Senior High School students. The students often only know about Pattimura.

The thickness of patriarchy culture keeps women history drowning in Indonesia historiography. Then it causes the content of women history in Indonesia history is located in a limited space in national history curriculum. The learning material about women history is lack and becomes 
BUDIARTI \& RACHMAWATI FAHMI,

Content of Women History in the Curriculum of History for Senior High School Comparison Study of 1994, 2004, and 2006

uninteresting thing for teachers to explain it more.

\section{Political Factor in Indonesia Historiography}

The long history about women struggle movement has stopped since the beginning of New Order era. Two things that assumed the happening such as the failure of education system in this country are misunderstanding and confused to interpret curriculum just as subjectmaterial.In1994Curriculum,students were given a mountain of material without watching the limit of interest allocation with the other curriculum factors to make the student aware to their environment (Yamin, 2009: 98). The government political interest decided the history subject material in school, together with the official interpretation of that historical event. Suharto regime affected the history curriculum because Suharto was one of the important figures at the end of Soekarno era. The effects that appeared in 1994 Curriculum had a good implication for Suharto figure, but not really in its truth because it's assumed as an effort to legitimate his authority as the president.

History as a subject function for making great appreciation to the heroes had a hidden political interest inside. The making of history curriculum was also based on the making of National History Book in six editions, called also as 'Baboon Book'. These books were used as the main reference in making the school textbook, started in elementary level, junior high school level, until senior high school level. Composing this book created such a kind of conflict that made the historian retreated. They, who retreated, chose to keep their academic principle rather than obeyed to the government will (Wineburg, 2006: xii). Asvi Warman Adam, a historian, even revealed in his paper in the prologue of Sam Wineburg's book; he explained that National History Book in Part V, there is a construction of who the enemy is (Indonesia Communist Party, supported by Soekarno), who the friend is (Indonesian Army, led by Suharto), who the traitor was (Indonesia Communist Party), who the hero is (Suharto, with the support of Indonesian Army), and who appropriate to rule because of the merit that has been made (Indonesian Army, through its dual functions) .

There was a distortion of Indonesian historiography. Indonesia historiography of women history was made for not disturbing the military patriarchy. Women positioned as the people who are loyal to the government (Jurnal Perempuan: 52). This history distortion felt by Indonesian Women Movement (Gerwani) organization. Cleverly, the military regime used sexual and wild illustration about the naked dancing Gerwani in Lubang Buaya to create a bad point of view about women in politics. Until now, the illustration about the naked dancing women still exists at the statue wall of five victim generals in Lubang Buaya. A black propaganda like this made a trigger of physical attack to all women whom assumed as Gerwani members and to the other organization which also assumed in the same ideology as Indonesia Communist Party. The message is clear: communist women, women in politics could endanger the safe and integrity of this nation (Jurnal Perempuan: 61).

Since the birth of New Order era, it's claimed so many history distortions that have been made for the political and elitist interest and Java centric. After reformation, historiography of women started to publish, such as Saskia Wieringa's book, 
a Netherland gender activist who write about women history and women studies, titled Penghancuran Gerakan Perempuan Indonesia (The Destruction of Indonesian Women Movement) in 1999. This book reveals about another side of Gerwani in New Order era which was manipulated; and of course it's about the Gerwani, on a separated case about $\mathrm{G} / 30 \mathrm{~S}$ affair. The revealed truth like that made the national history curriculum should be renewed.

Women are the part of history. Women also have their role in the struggle of the nation, and in maintaining and filling the independence. So many history facts talk about women, so the students actually should start to know, understand, comprehend, and explain about women role and their contribution in history that is as equal as men's.

\section{Content of Women History in 1994, 2004, and 2006 Curriculums}

The 1994 Curriculum, history subject in senior high school, Has set women movement history. Based on the student text book, the pioneer of women emantipation movement is R.A. Kartini, whose papers or letters wanted all Indonesian women to got their education because their task as a mother is a hard task. 'From the Darkness into the Light' is a book of her letters collection about her thought. This book was composed by Abendanon in 1899 . Its content is about women position in family, tradition, and the backwardness of women.

On the other hand, in this student text book also described about women organization such as PutriMahardika (1912), De Gorontalosche Mohammedaansche Vrouwen Vereniging in Minahasa, and Wanita Utomo in Yogyakarta. Also there was explained about the first Indonesian Women Congress in Yogyakarta in 1928 attended by the representatives of women organizations in Indonesia. The goals of the congress is about to create the same vision and mission to promote and advance Indonesian women, and make the fusion between the women organizations. In the congress, it was mentioned also about women fate in marriage and polygamy (Supriatna, 2002: 79-81).

In KBK and KTSP, women history could be seen in Hinduism-Buddism topic. There was Queen Sima, the ruler of Kalingga Kingdom. As written in the book, from Chinese cronic it was known that since 674, Kalingga Kingdom was ruled by a woman named Queen Sima. She was also known as a strong, firm, and discipline queen (Mustipo, 2004: 41).

Beside Queen Sima, there was also a famous queen from Majapahit, named Tribhuana Tunggadewi. As written in the book: Jayanegara died without left a single decendant. The right of authority given to Gayatri, but on that time Gayatri already be a bikhsuni. Because of that, the authority was given to Tribhuana Tunggadewi, replacing her mother. Tribhuana married with Kertawardhana, King of Singosari, and then had a child named Hayam Wuruk (Mustofo, 2004: 41). On the Islamic kingdom era, there should be Queen Kalinyamat, the ruler of Jepara, written in the student text book. But there is no explanation about Queen Kalinyamat in the text book (Mustofo, 2004: 41).

The big difference between the 1994 Curriculum and KBK-KTSP is lied in the materials given to students. The 1994 Curriculum gave a very compact materials 
BUDIARTI \& RACHMAWATI FAHMI,

Content of Women History in the Curriculum of History for Senior High School Comparison Study of 1994, 2004, and 2006

and it affected the more complete and complex text book than the KBK and KTSP text book. In KBK and KTSP curriculum text book there's a materials construction, so several topics could not be explained.

\section{Conclusion}

It can be concluded that the content of women history in history subject in senior high school based on the 1994 Curriculum, 2004 KBK, and 2006 KTSP did not really have any difference. In the learning materials, there's actually a little increasing, but not so significant. Women history in 1994 is about the women organizations in the national movement period. In KBK and KTSP, the content of women history was about in Hinduism-Buddhism era, and in colonial era. The explanation about women movement in colonial era could make students comprehend more about women roles and their organizations in order to do self struggle, in obtaining gender equality as well as in the nation integrity and Indonesia independence. There's also an additional topic about the first woman president in Indonesia, Megawati Soekarno Putri. She is one of pioneers of Indonesia democratization, because in her era there were a direct president election and direct legislative election.

Things that affected the content of woman history is in the learning method that applied by the curriculum. In the 1994 Curriculum, the learning method commonly held in lecturing method. This method made students do not really actively involve in learning process, so the meaning in history subject, included in woman history topic could not be really comprehended as well. In 2004 and 2006 Curriculum, students were sued to be more active in learning process; teachers were only as the facilitators to help students through several learning methods.

From counting the number of women history content, and comparing it with all the learning materials, it could be concluded that the Indonesia historiography character is androcentric. It happened because the patriarchy cultural factor is very tight in Indonesia society, beside because the political factor. Patriarchy culture exists since pre-historic age. Even more, this patriarchy culture is taken for granted by the majority of Indonesia society. The patriarchy culture creates gender inequality, and diminution of women role. In Indonesia history itself, there's only very limited source about women. Women are just only additional helper with less of heroism value.

The next factor is political factor. In composing national history curriculum, there's so many political factor interest, especialy in 1994 Curriculum when New Order era ruled. During the New Order era, there was dinumination of women movement in Indonesia. New Order regimen considered did so many ways to strenghten their authority, and it worked about 32 years. Women in politics were imapproriate. Women were only allowed to join government organization such as PKK and Dharma Wanita. Furthermore, government also sorted the history topics that could listed in history curriculum, and explained by the official explanation from the government.

After the end of New Order regime, there were many other side of history facts revealed. Society tried to speak their opinion through their paper about history created by the lie of new order regime, including about women history. One of the women history 
writers was Saskie Wieringa, who wrote 'Destruction of Women Movement'.

Women history should be educated to the students optimally in order to make students aware about women role and contribution in Indonesia history. Teachers could explain women role in every single of historical event, through this not only in one certain topic. With that kind of learning, the history material that given to the students could be more androgynous, where men and women role is equal and taking part together in history.

\section{REFERENCES}

Abdullah,T. ed. (2010). Sejarah Lokal Di Indonesia. Yogyakarta: Gadjah Mada University Press

Abdullah, T (2001). Nasionalisme dan Sejarah. Bandung: Satya Historika Ary, D, Jacobs, L C. \& Rezavieh, A. (1979). Introduction To Research In Education. New York : Holt, Rinehart and Wingston Inc.

Bhasin, K. (1996). Menggugat Patriarki. Yogyakarta: Kalyanamitra.

Best, J.W.,(1970). Research in Education.

New Jersey: Prentice-Hall, Inc.

Bloom, B. S., Krathwolh, D. R., Masia, B.

B. (1980). Taxonomy of Educational Objectives. New York : Longman Inc.

Douch, R. (1967). Local History and the Teacher. London: Routledge \& Kegan Paul

Cheppy, H. C. (1990). Pendidikan Moral dalam Beberapa Pendekatan.Jakarta: Depdikbud

Creswell, J.W.(1994). Research Design Qualitative\&QuantitativeApproaches. London: Sage Publication.
Creswell, J.W. (2010). Research Design: Pendekatan Kualitatif, Kuantitatif dan Mixed. Jakarta: Pustaka Pelajar.

Goubert, P. (1970). 'Local History' in Daedalus. Historical Studies Today. USA: The American Academy of Arts and Sciences

Hasan, S.H. (2012). Pendidikan Sejarah Indonesia, Isu dalam Ide dan Pembelajaran. Bandung: Rizqi Press

Hasan, S.H. (1997). Kurikulum dan Buku Teks Sejarah (Kongres Nasional Indonesia: Perkembangan teori dan metodologi dan orientasi pendidikan sejarah). Jakarta: Departemen Pendidikan dan Kebudayaan RI.

Kahin,G.M.T. (1995). Nasionalisme dan Revolusi di Indonesia.Jakarta: Pustaka Sinar Harapan dan UNS Press.

Kuntowijoyo. (1994). Metodologi Sejarah. Yogyakarta: Universitas Gadjah Mada

Mustopo, M. H. (2004). Sejarah Untuk Kelas 2 SMA Program Ilmu Sosial dan Bahasa. Jakarta: Yudhistira.

Purwanto, B. (2006). Gagalnya Historiografi Indonesiasentris?!. Yogyakarta: Ombak.

Pusat Kurikulum. (2003). Badan Penelitian dan Pengembangan. Departemen Pendidikan Nasional. Standar Kompetensi Mata Pelajaran Sejarah $S M A \& M A$. Jakarta: Pusat Kurikulum, Balitbang Depdiknas.

Sadli, S. (2010). Berbeda Tetapi Setara: Pemikiran Tentang Kajian Perempuan. Jakarta: Kompas.

Supardan, D, (2007). Pengantar Ilmu Sosial. Jakarta: Rineka Cipta

Supriatna, N. (2002). Sejarah Nasional Indonesia dan Umum Untuk Kelas II. Bandung: Grafindo Media Pratama. 
BUDIARTI \& RACHMAWATI FAHMI,

Content of Women History in the Curriculum of History for Senior High School Comparison Study of 1994, 2004, and 2006

Walby, S. "Theorizing Patriarchy", Journal Nasional, dan Global. Bandung: Sociology, 1989 Vol 23.

Historia Utama Press

Wineburg, S. (2006). Berpikir Historis. Yamin, M. (2009). Mengugat Pendidikan Jakarta: Yayasan Obor Indonesia. Indonesia, Belajar dari Paulo Freire

Wiriaatmadja, R. (2003). Pendidikan dan Ki Hadjar Dewantara. Jogjakarta:

Sejarah di Indonesia Perspektif Lokal, Ar Ruz Media. 